\title{
PENINGKATAN MUTU MADRASAH UNGGULAN PADA MTSN BARABAI KALIMANTAN SELATAN
}

\author{
Erlina Farida \\ Peneliti Puslitbang Pendidika Agama dan Keagamaan | Balitbang dan Diklat Kementerian Agama RI \\ Jl. MH Thamrin No. 06 Jakarta Pusat | Email: erlinafarida999@gmail.com
}

\begin{abstract}
Madrasah as a sub system of national education system has contributed to the cultural development of the nation. There has been misleading impression that madrasah is a marginal school. The Public Junior Secondary Madrasah (MTsN) of Barabai, South Kalimantan, as a model madrasah has proven to be the center of excellence. This paper provides a study on how MTSN Barabai improve their quality and develop innovative education for quality improvement. This study is purposed to determine how the quality policy and quality of innovation development are implemented. The results of this study demonstrate that the sincerity, hard work, and creativity of the managers in organizing student inputs to implementation process are successfully accomplished to achieve the objectives of student outputs as formulated in the madrasah policy.
\end{abstract}

Keywords: quality, model madrasah

\section{Abstrak}

Eksistensi madrasah sebagai sub sistem dari sistem pendidikan nasional telah memberikan kontribusi kultural bagi pembangunan bangsa. Kesan bahwa madrasah adalah sekolah marginal faktanya tidak benar. Madrasah Tsanawiyah Negeri (MTSN) Barabai Kalimantan Selatan sebagai madrasah model telah menunjukkan jati dirinya sebagai pusat keunggulan (center of excellence). Tulisan ini merupakan kajian tentang bagaimana upaya MTSN Barabai meningkatkan mutu dan mengembangkan inovasi pendidikan untuk perbaikan kualitasnya. Tujuan penelitian ini untuk mengetahui bagaimana implementasi kebijakan mutu dan inovasi pengembangan mutunya. Hasil kajian ini menunjukkan kesungguhan, kerja keras, dan kreatifitas pengelolanya mulai dari input siswa hingga proses implementasinya, berhasil mewujudkan output siswa sesuai tujuan yang dicanangkan dalam kebijakan madrasah.

Key words: mutu, madrasah unggulan

\section{PENDAHULUAN}

Sesuai dengan Undang-Undang No. 2 Tahun 1989 tentang Sistem Pendidikan Nasional, Madrasah adalah Sekolah Umum yang berciri khas Islam. Keluarnya UndangUndang Sisdiknas No 2 Tahun 1989 dan Undang-Undang Sisdiknas No. 20 Tahun 2003 memperkuat legitimasi bahwa madrasah tidak lagi terpinggirkan dari sistem pendidikan nasional karena lahirnya Undang-Undang tersebut mempertegas posisi madrasah yang secara legal formal adalah bagian dari subsistem pendidikan nasional. Oleh karenanya madrasah harus bisa menunjukkan eksistensinya dengan terus meningkatkan kualitas pendidikannya. Hal ini tidak semudah membalik tangan karena tuntutan mutu madrasah tidak hanya pada pendidikan agama saja akan tetapi juga pendidikan umum. Karakteristik madrasah yang berbeda dengan 
sekolah menjadikan nilai lebih sekaligus tantangan bagi madrasah untuk membuktikan bahwa perbedaan keduanya dimana madrasah punya kekhasan budaya lembaga pendidikan Islam yang bersentuhan dengan pesantren ini justru menjadi keunggulan madrasah dengan tanpa mengurangi kualitas pendidikan umum.

Seiring perkembangan dan perubahan jaman madrasah sebagai lembaga pendidikan Islam telah mengalami adaptasi, transformasi dan modernisasi. Saat ini bermunculan madrasah-madrasah unggul yang berdayasaing tinggi bahkan ada yang bisa mengungguli sekolah tanpa kehilangan jati dirinya baik itu madrasah negeri atau swasta yang beridentitas madrasah model, Insan Cendikia ataupun yang lainnya. Hal ini tentunya membanggakan karena prestasi yang diraih oleh siswa madrasah bukan hanya prestasi akademik dan non akademik saja akan tetapi juga prestasi keagamaan. Disamping itu proses pendidikan keagamaan di madrasah juga menghasilkan karakter kepribadian yang relatif kuat sesuai dengan visi pendidikan Islam yang bertujuan untuk mencapai keseimbangan pribadi yang dikembangkan dari semua aspek kehidupan manusia baik secara individu maupun kelompok untuk mencapai kesempurnaan hidup di dunia maupun di akhirat.

Madrasah Tsanawiyah Negeri Barabai adalah madrasah terunggul di Kalimantan selatan menurut penilaian Kantor Kementerian Agama Provinsi Kalimantan Selatan. Kriteria yang paling menonjol dari sisi akademik adalah madrasah ini dalam kurun waktu lima tahun terakhir nilai UN nya selalu tertinggi di atas nilai UN sekolah se-Kalimantan Selatan. Bahkan di tahun 2013 siswa dari madrasah ini masuk lima besar tertinggi tingkat Provinsi Kalimantan Selatan. Madrasah ini juga kaya prestasi baik di bidang non akademik maupun keagamaan. Padahal madrasah ini berada di sebuah desa yaitu Mandingin kecamatan Barabai sebuah kota kecil di sebelah barat kota Banjarmasin ibukota Kalimantan Selatan yang jauh dari keramaian kota. Oleh karenanya MTsN Barabai ini menarik dan perlu diteliti secara mendalam bagaimana perjuangannya hingga bisa unggul melampaui prestasi sekolah.

Tujuan penelitian ini adalah untuk: 1) Mengetahui impementasi kebijakan peningkatan mutu MTsN Barabai dan 2). Mengetahui bagaimana inovasi pengembangan mutu MTsN Barabai.

\section{Kerangka Konseptual}

\section{Mutu}

Undang-undang Republik Indonesia Nomor 20 tahun 2003 menimbang bahwa Sistem Pendidikan Nasional harus menjamin pemerataan kesempatan pendidikan, peningkatan mutu serta relevansi dan efisiensi manajemen pendidikan untuk menghadapi tantangan sesuai dengan tuntutan perubahan kehidupan lokal, Nasional dan global sehingga perlu dilakukan pembaharuan pendidikan secara terencana, terserap dan berkesinambungan.

Perihal penjaminan mutu lembaga pendidikan juga tertuang dalam peraturan pemerintah RI Nomor 19 tahun 2005 pada bab XV, dimana setiap satuan pendidikan jalur formal maupun jalur non formal wajib melakukan penjaminan mutu pendidikan, penjaminan mutu tersebut bertujuan untuk memenuhi atau melampaui Standar Nasional Pendidikan. ${ }^{1}$

Mutu pendidikan merupakan salah satu tolak ukur yang menentukan martabat atau kemajuan suatu bangsa. Dengan mencermati mutu pendidikan suatu bangsa/negara, seseorang akan dapat memperkirakan peringkat negara tersebut di antara negaranegara di dunia. Oleh karena itulah, bangsa yang maju akan selalu menaruh perhatian besar terhadap dunia pendidikannya, dengan melakukan berbagai upaya untuk meningkatkan mutu pendidikan.

${ }^{1}$ PP No. 19 tahun 2005, Standar Nasional Pendidikan 
Mutu adalah kecocokan penggunaan produk (fitness for use) untuk memenuh kebutuhan pelanggan. ${ }^{2}$

Menurut Sallis mutu adalah upaya untuk memenuhi kebutuhan pelanggan, masih dalam buku yang sama Evard mengartikan mutu sebagai keunggulan (Excellence) dengan alasan cocok dengan tujuan. Definisi lain mengatakan "Quality is often defined in term outcome to match a costumer satisfaction". Dalam konteks mutu sekolah, kepuasan prang tua, masyarakat, dalam pihak terkait (stakeholder) terhadap lulusan yang berkualitas dan pelayanan sekolah yang baik merupakan kata kunci sekolah yang diandalkan. ${ }^{3}$

Dari uraian di atas bisa disimpulkan bahwa yang dimaksud mutu ialah nilai moral terkait pelayanan dengan kriteria persyaratan untuk memenuhi kebutuhan dan kepuasan pelanggan. Jadi dalam hal ini madrasah mempunyai konsep kualitas pelayanan yang digunakan untuk memenuhi spesifikasi tertentu dan memuaskan pelanggan sesuai dengan kebutuhannya.

\section{Madrasah Unggul}

Dalam Kamus Besar Bahasa Indonesia dijelaskan bahwa yang dimaksud dengan unggul adalah lebih tinggi, pandai, kuat, dan sebagainya daripada yang lain; terbaik; terutama. Sedangkan keunggulan artinya keadaan unggul; kecakapan, kebaikan dan sebagainya yang lebih dari pada yang lain. ${ }^{4}$

Secara ontologis sekolah unggul dalam perspektif Departemen Pendidikan Nasional adalah sekolah yang dikembangkan untuk mencapai keunggulan dalam keluaran (output) pendidikannya. Untuk men-

${ }^{2}$ Joseph M. Juran. 1993. Quality Planning and Analysis/ Third Edition. New York: Mc Graw Hill Inc., h. 98.

3 Syafaruddin. 2008. Efektifitas Kebijakan Pendidikan. Jakarta: Rineka Cipta. .

${ }^{4}$ Peter Salim dan Yenny Salim, Kamus Bahasa Indonesia Kontemporer (Jakarta: Modern English Press, 1991), h. 11685. capai keunggulan tersebut maka masukan (input), proses pendidikan, guru dan tenaga kependidikan, manajemen, layanan pendidikan, serta sarana penunjangnya harus diarahkan untuk menunjang tercapainya tujuan tersebut. ${ }^{5}$

Dengan demikian sekolah/madrasah unggulan dapat didefinisikan sekolah/ madrasah yang dikembangkan dan dikelola sebaik-baiknya dengan mengarahkan semua komponennya untuk mencapai hasil lulusan yang lebih baik dan cakap daripada lulusan sekolah lainnya.

Madrasah atau sekolah yang memiliki keunggulan kompetitif akan terus mengejar prestasinya sehingga mampu bersaing dengan sekolah lain, walaupun sudah mendapat bantuan dari pemerintah sekolah unggulan ini tetap dan terus berusaha meningkatkan kualitas keunggulannya, baik dalam hal manajemennya maupun outputnya. Pelayanan terhadap siswa dikelola dengan baik sehingga mereka dapat belajar dalam keadaan kondusif. Lulusan yang berkualitas akan dicari oleh masyarakat untuk diberdayakan potensinya yang diperoleh ketika disekolah.

Sedangkan mengembangkan madrasah unggulmerupakansatuaktivitas yangkompleks karena berkaitan dengan pengembangan sebuah organisasi sebagai wadahterhimpunnya komunitas yang memiliki latar belakang yang beragam. Membangun budaya unggul dalam sebuah organisasi, termasuk budaya unggul dalam lingkungan madrasah memerlukan proses dan waktu yang panjang.

Mengembangkan keunggulan dalam sebuah sekolah/madrasah melalui pendekatan budaya organisasi berarti mengorganisasi beragam manusia dan melebur mereka dalm satu pikiran yang terarah ke pembuatan produk dan layanan terbaik, pemuasan pelanggan sepenuhnya dan pemeliharaan warga organisasi itu sendiri. Berikut ini hal-

${ }^{5}$ Muhammad, "Konsep Pengembangan Madrasah Unggul”, Kreatif, Vol. 4, No. 1 (Januari 2009). h. 39. 
hal yang mendukung untuk mengembangkan organisasi madrasah dalam mencapai keunggulan, di antaranya:

Menurut Goleman madrasah yang dikategorikan unggul harus meliputi tiga aspek yaitu:

\section{Input}

Daniel Goleman, dalam bukunya, menyebutkan bahwa kemampuan mengenal diri dan lingkungannya adalah kemampuan untuk melihat secara objektif atau analisis, dan kemampuan untuk merespon secara tepat, yang membutuhkan kecerdasan otak/ Intelligence Quotien (IQ) dan kecerdasan emosional/Emotional Quotien (EQ). Di samping itu, kecerdasan spiritual/Spiritual Quotien (SQ) calon siswa hendaknya dapat terukur saat seleksi siswa baru. Dengan demikian, tes seleksi siswa baru hendaknya dapat mengukur ketiga aspek kecerdasan atau bahkan dapat mengukur berbagai kecerdasan/multy intellegence. Sehingga, tes seleksi siswa baru tujuannya tidak semata-mata untuk menerima atau menolak siswa tersebut tetapi jauh ke depan untuk mengetahui tingkat kecerdasan siswa. Dengan data tingkat kecerdasan siswa tersebut dapat digunakan sebagai dasar untuk menentukan proses pembinaannya dan bahkan dapat untuk menentukan target atau arah pendidikan di masa depan.

\section{Proses}

Proses belajar-mengajar sekolah unggul ini setidaknya berkaitan dengan kemampuan guru, fasilitas belajar, kurikulum, metode pembelajaran, program ekstrakurikuler, dan jaringan kerjasama

\section{Output}

Sekolah unggul harus menghasilkan lulusan yang unggul. Keunggulan lulusan tidak hanya ditentukan oleh nilai ujian yang tinggi. Indikasi lulusan yang unggul ini baru dapat diketahui setelah yang bersangkutan memasuki dunia kerja dan terlibat aktif dalam kehidupan bermasyarakat. Kemampuan lulusan yang dihasilkan dirasa unggul, bila mereka telah mampu mengembangkan potensi intelektual, potensi emosional, dan potensi spiritualnya dimana mereka berada. ${ }^{6}$

Dari berbagai definisi di atas bisa disimpulkan bahwa madrasah unggul adalah madrasah yang bisa menunjukkan ciri-ciri atau memenuhi kriteria keunggulan komparatif dan kompetitif, berprestasi akademik maupun non akademik, unggul dari segi input, proses dan output siswa. Dengan demikian madrasah unggulan dapat didefinisikan sekolah yang dikembangkan dan dikelola sebaik-baiknya dengan mengarahkan semua komponennya untuk mencapai hasil lulusan yang lebih baik dan cakap daripada lulusan sekolah lainnya.

\section{Metodologi}

Pendekatan penelitian adalah pendekatan kualitatif. Glesne dan Peshkin menandaskan bahwa dalam penelitian kualitatif peneliti mengumpulkan kata-kata melalui percakapan dengan sejumlah kecil orang, menghimpun berbagai dokumen dan mengobservasi perilaku. ${ }^{7}$

Dengan demikian, pemilihan metode deskriptif didasarkan pada kenyataan bahwa peneliti memusatkan perhatian penuh pada obyek yang diteliti, baik key person maupun informan yang menjadi lokus studi untuk mendapatkan gambaran yang komprehensif tentang implementasi kebijakan mutu dan pengembangan inovasi mutu di MTsN Barabai sebagai madrasah model dan unggulan di Provinsi Kalimantan Selatan.

Teknik pengumpulan data menggunakan observasi, wawancara, dan studi dokumentasi.

\footnotetext{
${ }^{6}$ Petrus Trimantara, "Sekolah Unggulan: Antara Kenyataan dan Impian” Jurnal Pendidikan Penabur, Vol. 6, No.08 (Juni 2007), h. 7.

7 Glesne, Corrin dan Peshkin.1992. Becoming Qualitative Researchers: An Introduction. New York: Longman Publishing Group. h..5.
} 
Observasi dilakukan untuk mengamati situasi madrasah indoor maupun outdoor dan lingkungan madrasah berikut budaya madrasahnya. hasil observasi dilengkapi deskripsi terhadap peristiwa atau kegiatan yang relevan dengan karakter menonjol itu. Wawancara mendalam dilakukan dengan kepala madrasah, guru, siswa, tokoh masyarakat atau komite madrasah, dan tenaga administrasi. Studi dokumentasi dilakukan untuk mendapatkan data tertulis tentang semua aspek komponen madrasah yang diperlukan terkait madrasah unggul dan khas seperti kebijakan resmi, kurikulum, statistik data input, output siswa, prestasi akademik dan non akademik, tenaga pendidik dan kependidikan, dan lain-lain.

Analisis dalam penelitian ini menggunakan teknik deskriptif kualitatif dengan metode induktif. Seluruh data yang ada baik dari hasil observasi, wawancara, studi dokumentasi dikaji dan dianalisis dan dijadikan laporan.

\section{HASIL DAN PEMBAHASAN}

\section{Gambaran Umum Madrasah}

Madrasah Negeri Barabai terletak kurang lebih $165 \mathrm{Km}$ dari Kota Provinsi Kalimantan Selatan, dengan waktu tempuh normal 4 jam dari Kota Banjarmasin melewati Kota Banjarbaru, Martapura, Kabupaten Tapin dan Hulu Sungai Selatan. Madrasah Tsanawiyah Negeri Barabai ini persisnya terletak di sebelah selatan dari Kabupaten Hulu Sungai Tengah dengan waktu tempuh normal 10 menit dari Kota Barabai, terletak di Desa mandingin namun masih termasuk kecamatan Barabai Kabupaten Hulu Sungai Tengah Provinsi Kalimantan Selatan.

Letak madrasah ini begitu strategis karena berada di dua jalan yang berbeda yang pada awalnya Madrasah Tsanawiyah Negeri Model Barabai hanya berdiri di sebuah kawasan Jalan Abdul Ridhani namun dikarenakan semakin banyaknya anak didik yang ingin bersekolah di
Madrasah Tsanawiyah Negeri Model Barabai, maka pihak Madrasah pun dari tahun ketahun melakukan pemekaran ruang belajar hingga sampai berada di jalan Bintara.

Jalan Abdul Muis Ridhani Nomor 80 yang notabane adalah jalur lintas Provinsi Kalimantan Kedua jalur inilah yang menjadikan pihak Madrasah lebih mudah membagi dua jalur kepulangan siswa, yang mana jalan Abdul Muis Ridhani sebagai jalur pulangnya khusus siswa putra dan Jalan Bintara untuk kepulangan siswa putri.

Madrasah Tsanawiyah Negeri Model Barabai pada awalnya berdiri atas gagasan para karyawan Departemen Agama Kab. HST (sekarang Kamenag Kab. Hulu Sungai Tengah) yang ingin mendirikan sebuah sekolah yang bernafaskan Islami di Kabupaten Hulu Sungai tengah.

Awalnya MTsN Model Barabai adalah pecahan dari PGAN 6 tahaun Barabai. Untuk tingkat SLTP/MTs didirikan MTsN Barabai, sedangkan untuk lanjutan (SLTA) diteruskan dengan nama Sekolah PGAN 3 Tahun Barabai yang selanjutnya berubah menjadi MAN 2 Barabai. Pada tahun 1976 didirikanlah sebuah Madrasah yang beralamat di Jalan Abdul Muis Ridhani No. 80 Desa Mandingin Kecamatan Barabai, tak jauh dari Kantor Departemen Agama Kabupaten Hulu Sungai Tengah. Dari tahun ke tahun Madrasah Tsanawiyah Negeri Model Barabai mengalami perkembangan yang signifikan secara kuantitas maupun kualitas. Secara kuantitas terlihat dari banyaknya peminat siswa SD ataupun dari MIN yang ingin melanjutkan ke Madrasah Tsanawiyah Negeri Model Barabai.

Pada tahun 1998 oleh Direktur Jenderal Pembinaan Kelembagaan Agama Islam menjadikanMadrasan Tsanawiyah Negeri Barabai salah satu dari tiga Madrasah Model yang ada di Kalimantan Selatan dan menjadi sekolah favorit di Kabupaten Hulu Sungai tengah.

Salah satu prestasi yang paling membanggakan pada tahun 2005 Madrasah 
Tsanawiyah Negeri Model Barabai meraih Juara ke 2 Madrasah Berprestasi Tingkat Nasional.

Sosok penggagas pendirian madrasah ini adalah Drs. Abdullah Sihamkari salah satu pegawai Departemen Agama yang juga salah satu pengagas berdirinya Madrasah Negeri Barabai diberi kepercayaan oleh Kepala Departemen Agama Kabupaten Hulu Sungai Tengah Waktu itu untuk menjabat sebagai Kepala Madrasah Negeri Barabai yang pertama dan beliau menjabat menjadi kepala Madrasah Negeri Barabai sejak tahun 1976 sampai dengan 1979 dan sampai sekarang Madrasah Negeri Barabai telah berganti pimpinan sebanyak 8 kali.

Madrasah ini juga berada di lingkungan perkampungan yang warga dan aparat desa terjalin hubungan harmonis dengan pihak madrasah ini terbukti dengan antusias warga sekitar yang selalu berperan aktif melapor kepada pihak sekolah jika ada siswa yang masih keluyuran atau membolos saat pembelajaran di laksanakan dan turut sertanya menjaga keamanan madrasah jika ada orang asing yang di anggap akan menganggu nyamannya pembelajaran di madrasah serta adanya peran serta aparat desa dalam pembinaan PKS Patroli Keamanan SekolahMTsN Barabai.

Suasana yang tergambar dalam lingkungan madrasah adalah bernuansa agamis, ini bisa terlihat dari kebiasaan yang di berlakukan pihak madrasah dalam membimbing siswa untuk selalu taat beribadah, berperilaku sopan, menghormati orang tua dan guru. Di pagi hari tampak pembiasaan shalat dhuha berjama'ah secara terjadwal, siang hari shalat zuhur berjama'ah seluruh siswa yang tidak berhalangan dan siswa yang berhalangan pun di wajibkan berkumpul di perpustakaan untuk membaca shalawat nariah secara berjamaah. Saat siswa turun dari sepeda ketika memasuki halaman madrasah, selalu memberi salam jika bertemu guru ataupun pegawai madrasah lainnya.

Tak hanya pembelajaran wajib yang diberikan oleh pihak madrasah kepada siswa madrasah, hal ini bisa dilihat dari kegiatan kegiatan ekstrakurikuler yang dilaksanakan pihak madrasah, antara lain Pramuka PMR, Drum band, Karate, Sepak Bola, Bola Voli, Habsy (pembacaan syair maulid Nabi Muhamamad) Tilawah, TPA (bagi siswa yang kurang lancar mengaji) serta pelaksanaan kegiatan persiapan menghadapi sebuah event pertandingan maupun perlombaan antara lain: Liga Pelajar Indonesia, Aksioma, Olympiade Sain, Jambore, Perkemahan PMR, Parade Drum Band, Pertandingan Bola Voli, Futsal dan Karate juga persiapan lomba dan tandingan dalam rangka memeriahkan HAB Kemenag khusus pelajar MTs yang dilaksanakan setiap bulan Desember serta pelaksanaan LDKS guna menyiapkan mental para calon anggota OSIS yang langsung di laksanakan oleh pembina OSIS.

Dengan adanya kegiatan tambahan yang dilaksanakan oleh pihak madrasah, semua jerih payah terbayar dengan banyaknya prestasi prestasi yang diukir oleh para siswa yang bisa dilihat dari deretan piala dan piagam yang terpajang di lemari kaca yang berderet di depan kantor Kepala Madrasah dan ruang $\mathrm{TU}$, baik prestasi bidang pendidikan, lomba dan pertandingan olahraga, lomba kebersihan, lomba pramuka, lomba PMR dan lain lain, baik tingkat Kecamatan, tingkat Kabupaten, Provinsi bahkan tingkat Nasional.

Untuk prestasi akademik tercatat selama kurun waktu diterapkannya ujian Nasional Madrasah Tsanawiyah Negeri Model Barabai sejak tahun ajaran 2010/2011 untuk tingkat kabupaten selalu berada diurutan teratas bahkan pada tahun 2011/2012 dan tahun 2012/2013 juara I tingkat provinsi.

Tabel 1.

Data Rata-rata Nilai UN 5 Tahun Terakhir

\begin{tabular}{|l|l|l|l|l|l|}
\hline No & Mata Pelajaran & 2010 & 2011 & 2012 & 2013 \\
\hline 1. & Bahasa Indonesia & 7,84 & 7,43 & 8,28 & 7,67 \\
\hline 2. & Bahasa Inggris & 8,16 & 8,50 & 8,16 & 7,59 \\
\hline 3. & Matematika & 8,63 & 8,52 & 8,95 & 8,20 \\
\hline 4. & IPA & 8,17 & 8,77 & 9,31 & 7,56 \\
\hline
\end{tabular}

Pada tahun 2014 lima siswa MTsN Barabai nilai UN berhasil meraih lima besar 
tertinggi tingkat provinsi Kalimantan Selatan, keseluruhannya rata-rata semua pelajaran yang diujikan nilainya adalah 9,3. Sedangkan prestasi tenaga pendidik selama dua tahun berturut-turut selalu mendapatkan juara guru berprestasi, yaitu pada tahun 2011 dan 2012.

\section{Impementasi Kebijakan Peningkatan Mutu Madrasah}

Kebijakan sekolah adalah core dalam frame kebijakan pendidikan. Unttuk mencapai peningkatan nutu madrasah sebagai konsekuensinya Kepala Madrasah dituntut untuk memformulasikan, mengimplementasikan, dan mengevaluasi kebijakan pendidikan. Duke dan Canady menyatakan bahwa suatu kebijakan sekolah sangat penting bagi kehidupan siswa dan para guru, karena berkaitan dengan pembelajaran dalam rangka meningkatkan efektivitas sekolah. ${ }^{8}$ Sedangkan Gamage dan Pang menyatakan bahwa kebijakan sekolah dibuat tidak hanya sekedar memberi arah bagi tindakan operasional sekolah yang bernilai strategis, teapi juga memperkuat komitmen tugas, kerjasama, akuntabilitas, bahkan pemberdayaan staf. Manfaat kebijakan diarahkan untuk meraih kepuasan harapan stakeholders pendidikan. ${ }^{9}$

Setiap institusi pendidikan tentunya bertujuan menciptakan peserta didik, putraputri Indonesia dan ingin mengembangkan potensi anak didik menjadi manusia yang beriman dan bertaqwa kepada Tuhan Yang Maha Esa, berakhlak mulia, sehat, berilmu, kreatif, mandiri dan menjadi warga Negara yang demokratis serta bertanggung jawab. Sebagaimana yang telah di amanatkan UndangUndang Republik Indonesia Nomor 20 Tahun 2003 tentang sistem Pendidikan Nasional dan Peraturan Pemerintah Republik Indonesia

${ }^{8}$ Duke, Daniel L and Robert Lynn Canady. 1999. School Policy. New York: The Drayden Press.

${ }^{9}$ Gamage, David Thenuwara and Nicholas Sun-Keung Pang. 2003. Leadership and Management in Education. Hongkong: he Chinese University Press.
Nomor 19 Tahun 2005 tentang Standar Nasional Pendidikan, untuk memenuhi amanat tersebut MTsN Barabai sebagai lembaga pendidikan tingkat menengah memandang dan merasa perlu untuk melakukan berbagai kebijakan dalam rangka peningkatan mutu dan kualitas pendidikan di Madrasah antara lain sebagai berikut:

\section{Visi Madrasah}

Perkembangan dan tantangan masa depan seperti perkembangan ilmu pengetahuan dan teknologi; globalisasi yang sangat cepat; era informasi; dan perubahan kesadaran masyarakat dan orang tua terhadap pentingnya pendidikan memicu Madrasah untuk merespon tantangan sekaligus peluang itu. MTsN Model Barabai sebagai salah satu lembaga pendidikan formal yang sekaligus sebagai penyelenggara pendidikan setingkat Sekolah Menengah Pertama yang merupakan satu-satunya berstatus negeri di Kecamatan Barabai Kabupaten Hulu Sungai Tengah memiliki citra moral yang menggambarkan profil madrasah yang diinginkan di masa datang yang diwujutkan dalam Visi Madrasah, adapun Visi Madrasah tersebut adalah "Unggul dalam prestasi berdasarkan Imtaq, Iptek, dan Islami yang berwawasan Lingkungan secara terpadu, seimbang dan berkesinambungan".

Visi tersebutdi atas mencerminkan citacita Madrasah yang berorientasi ke depan dengan memperhatikan potensi kekinian, sesuai dengan norma dan harapan masyarakat. Oleh karena itu, madrasah menentukan langkah-langkah strategis yang dinyatakan dalam misi.

\section{Misi Madrasah}

Sementara itu, misi dari Madrasah adalah: 1). Mengkoordinasikan kehidupan yang islami kepada seluruh warga madrasah, 2). Melaksanakan pembelajaran dan bimbingan serta memfungsikan perpustakaan secara efiktif, sehingga setiap siswa dapat berkembang 
secara optimal. 3). Melaksanakan pembinaan disiplin madrasah dengan melibatkan seluruh warga madrasah untuk mewujudkan 10K. 4). Melaksanakan gegiatan yang positif, kreatif dan inovatif. 5). Melaksanakan kegiatan pembinaan seni, seperti vocal grup, rebana, drum band, puisi, nasyid islami, seni tari dan tilawah dan lain-lain. 6). Melaksanakan pembinaan olah raga, seperti sepak bola, basket, bola volley, fotsal, bulu tangkis, silat dan karate. 7). Membiasakan seluruh warga madrasah untuk melakukan kebersihan dan selalu disiplin dalam segala hal. 8). Lulusan mampu berwirid, bertahlil dan hafal surah surah pendek dalam juz'Ama. 9). Menumbuhkan semangat keunggulan secara intensif kepada seluruh warga madrasah. 10).Menumbuh kembangkan semua warga madrasah akan keperdulian terhadap lingkungan dan pemenfaatan barang bekas 11).Merehabilitasi dan penambahan sarana prasarana madrasah. 12).Menumbuhkan sikap social melalui kegiatan pramuka, PMR, Patroli keamanan madrasah, paskibra dan gerakan saudara asuh serta sumbangan untuk yang mendapat musibah dan lain-lain. 13). Menegakkan dan menerapkan disiplin kepada seluruh peserta didik, pendidik, dan tenaga kependidikan.

\section{Peserta Didik}

Dalam rangka meningkatkan kualitas dan disiplin peserta didik diwajibkan untuk memenuhi semua tata tertib siswa yang berlaku di madrasah yang telah disosialisasikan kepada seluruh siswa dan orang tua/wali siswa serta pihak komite madrasah pada setiap awal tahun pelajaran baru, yang di antaranya: hadir ke madrasah tepat waktu 5 menit sebelum jam masuk, tidak boleh menggunakan kendaraan bermotor sendiri saat berangkat sekolah, memakai sepatu hitam, dan lain-lain.

\section{Pendidik}

Guru sebagai tenaga pendidik adalah tokoh panutan dan identifikasi bagi para peserta didik, dan lingkungannya. Oleh karena itu pendidik harus memiliki standar kualitas pribadi tertentu, yang mencakup tanggung jawab, wibawa, mandiri, dan disiplin. Sehingga sang pendidik diwajibkan untuk dapat melakukan kewajibannya dengan baik di antaranya: hadir ke madrasah 5 menit sebelum jam pelajaran di mulai dan pulang 15 menit setelah berakhir jam pelajaran ( $07.00 \mathrm{~s} / \mathrm{d} 14$. 15), menjalankan tugas pengajaran dengan baik, menyiapkan bahan ajar dengan baik, dan lain-lain.

\section{Tenaga Kependidikan}

Tenaga kependidikan sebagai petugas yang berperan dalam kelangsungan administrasi sebuah lembaga pendidikan tentunya perannya sangat penting untuk kelancaran suatu proses pendidikan sehingga diharapkan dapat bekerja sesuai dengan job yang sudah ditentukan.

\section{Strategi Input Siswa Baru}

Di antara strategi input siswa baru, yaitu: 1). Menetapkan standar nilai untuk Calon Peserta Didik Baru. Dalam rangka penerimaan calon peserta didik baru untuk tiap tahun ajaran baru di laksanakan pada bulan April dan Juni dengan melalui berbagai tahapan di antaranya: a. Penerimaan calon peserta didik baru untuk lulusan SD maupun MI dilakukan 2 sosialisasi ke sekolah-sekolah pada maret oleh panitia PPDB di samping itu di bagikan brosur serta selebaran/pengumuman yang berisikan syarat-syarat dan ketentuan pendaftaran. b. Penerimaan calaon peserta didik baru dilakukan dua gelombang yaitu gelombang I bagi siswa berprestasi/jalur khusus dengan syarat memiliki nilai minimal 8,00 nilai ratarata raport kelas $\mathrm{V}$ semester I dan II serta kelas IV semester I, kemudian gelombang II untuk umum atau reguler. c. Seleksi penentuan kelulusan untuk calon peserta didik baru pada gelombang I di lakukan berdasarkan rengking nilai teratas dari nilai rata-rata raport dengan mempertimbangkan prestasi belajar dan 
prestasianak didik pada bidang keahlian atau perlombaan. d. Seleksi penentuan kelulusan untuk calon peserta didik baru dari gelombang II yaitu jalur umum atau regoler dilakukan dengan cara tes tertulis untuk bidang mata pelajaran yang di uji nasionalkan serta PAI dan praktek Ibadah yaitu praktek shalat dan baca tulis Al-Qur'an. 2). Melakukan penyempurnaan kurikulum yang sesuai dengan kebutuhan daerah. 3). Melengkapi berbagai alat peraga serta bahan ajar yang sudah ada. 4). Menciptakan suasana madrasah yang nyaman dan aman. 5). Menciptakan madrasah yang berwawasan lingkungan. 6). Madrasah diberi kebebasan untuk melakukan kegiatan-kegiatan yang mendatangkan penghasilan (income generating activities), misalnya meminta bantuan kepada perusahaan-perusahaan setempat untuk memberikan bea siswa, memberikan kesempatan kepada orang tua siswa melalui komite Madrasah utuk peluang amal pada setiap Romadhan, pelayanan koperasi baik bagi guru maupun bagi siswa, sehingga sumber keuangan tidak semata-semata bergantung pada pemerintah. 7). Melengkapi sarana dan prasarana yang ada secara bertahap. Hal ini didasari oleh kenyataan bahwa madrasah yang paling mengetahui kebutuhan sarana dan prasarana baik kecukupan, kesesuaian, maupun kemuthahirannya dirancang secara khusus untuk kepentingan pembelajaran. Sarana dan prasarana disini meliputi: media pembelajaran, buku-buku pelajaran, alat alat olah raga dan keswenian serta alat-alat praktek dan lainlain. 8). Musyawarah Guru Mata Pelajaran yang diadakan di madrasah merupakan salah satu cara untuk memecahkan problem guru sekaligus untuk meningkatkan kemampuan guru, tujuan adanya musyawarah itu sendiri adalah untuk menyatukan pandangan guru terhadap materi pembelajaran serumpun, konsep umum pendidikan dan fungsi madrasah dalam mencapai tujuan pendidikan. Selain itu untuk menyatukan pendapat tentang metodemetode yang akan digunakan dalam proses belajar-mengajar serta pemecahan segala permasalahan yang adadidalam pengajaran.Jadi dengan adanya musyawarah dapat membantu baik individu ataupun kelompok untuk menyamakan pandangan serta menganalisis problem-problem dalam pengajaran serta mencari penyelesaiannya. 9). Pelatihan (training), pelatihan ini merupkan salah satu teknik supervisi pendidikan yang dimaksudkan untuk meningkatkan kemampuan guru dalam proses belajar-mengajar, hal ini sesuai dengan pengertian pelatihan yaitu suatu usaha atau kegiatan yang bertujuan untuk meningkatkan taraf ilmu pengetahuan dan kecakapan para guru, dengan demikian keahlian yang dimiliki guru semakin bertambah luas dan mendalam. 10). Membagi jumlah siswa yang tidak terlalu banyak didalam kelas agar lingkungan belajar lebih kondusif. 11). Meningkatkan komunikasi yang baik dalam segala hal baik dalam pengambilan keputusan, evaluasi, dan lain-lain melalui rapat Komite, Terutama rapat antar warga madrasah dan juga antara madrasah dengan masyarakat, sehingga kegiatankegiatan yang dilakukan oleh masing-masing warga madrasah dapat diketahui, terutama pada perkembangan peserta didik tentang pengembanagn keimanan dan ketaqwaan kepada Allah SWT, serta akhlak mulia peserta didik seoptimal mungkin.

\section{Budaya Madrasah}

"Culture refers to the values, beliefs system, orms, and ways of thinking that are characteristic of the people in organization." 10 Budaya merujuk pada nilai-nilai, sistem keyakinan, normanorma, dan cara berpikir yang merupakan karakteristik dan anggota-anggota dalam organisasi. Dalam budaya selalu ada asumsi, semangat, keyakinan dan komitmen bersama untuk mencapai tujuan organisasi yang di dalamnya juga terdapat tujuan pribadi. Tujuan organisasi tecapai berarti tujuan pribadi tercapai. Stavin menandaskan bahwa: "culture:

${ }^{10}$ Owens Robert G. 1991. Organizational Behavior in Education. Boston: Allyn and Bacon. 
the language, attitudes, ways of behaving, and other aspects of life tst charcterize a group of people"11

Dari deskripsi di atas bisa disimpulkan bahwa budaya organisasi adalah ciri khas suatu organisasi yang terbentuk dari proses interaksi antar anggotanya yang dapat dilihat dari spirit, kepercayaan, keterpaduan dan pemecahan masalah dengan tim. Di MTsN Barabai ada beberapa kegiatan pembiasaan yang merupakan ciri dan khas budaya yang berlaku di madrasah ini antara lain sebagai berikut: 1). Mengucapkan salam setiap masuk kedalam kelas 2). Berjabat tangan setiap akhir kegiatan pembelajaran 3). Menundukkan badan setiap berpapasan dengan guru atau siswa yang lebih senior. 4). Melaksanakan shalat dhuha dan shalat dhuhur berjama'ah. 5). Membaca surah-surah pendek setiap pagi pada jam 0.6). Pembacaan surah Yassin pada pagi jum'at. 7). Pembacaan wirid pada pagi sabtu. 8). Gerakan saudara asuh pada hari Senin Gerakan saudara asuh adalah suatu bagian dari usaha dan upaya madrasah dalam ikut serta membantu sebagian siswa dan siswi yang dari keluarga kurang mampu yang tidak terjaring dalam program Bantuan Beasiswa Siswa Miskin( BSM ) dalam memenuhi kebutuhan perlengkapan sekolah seperti Pakaian, tas, alat tulis sepatu dan lainlain. Serta sebagai wahana bagi siswa dalam penerapan cinta sesame dan rasa kepedualian terhadap yang kurang mampu. 9). Upacara pagi senin. 10). Kegiatan jum'at amal. Kegiatan jum'at amal yang dilaksanakan setiap hari jum'at bertujuan agar para siswa dapat berbagi dan beramal jariah menyisihkan sebagaian uang jajannya untuk kelangsungan tempat ibadah yang ada di MTsN Model Barabai. 11). Melaksanakan ta'ziah bagi keluarga besar MTsNModel Barabai yang terkena musibah atau meninggal dunia. 12). Senam pagi. Senam pagi di laksanakan pada setiap hari jum'at yang berlangsung sejak pukul $07.00 \mathrm{~s} / \mathrm{d}$ 07.30 wita yang di ikuti oleh seluruh siswa dan siswi serta tenaga pendidik dan kependidikan MTsN

${ }_{11}$ Robert E. Stavin. 1991. Educational Psychology: Theory and Practice. New Jersey: Prentice Hall Inc. h. 448.
Model Barabai. 13). Jum'at bersih. Kegiatan jum'at bersih dilaksakan pada setiap pagi jum'at seusai kegiatan senam pagi, hal ini merupakan bentuk kometmen Madrasah yang berwawasan lingkungan serta sebagai wujut kepedulian seluruh kompunen madrasah terhadap lingkungan sehingga lingkungan madrasah tampak selalu bersih dan tertata dengan baik.

\section{Pengembangan Inovasi Mutu Madrasah}

Beragam bentuk program telah dilakukan MTsN Barabai untuk mengembangkan inovasi dalam upaya meningkakan mutu madrasah. Berikut ini adalah gambarannya.

\section{Penguatan PAI}

Pendidikan Agama Islam secara umum diintegrasikan secara seimbang dan menjadi roh/jiwa pengetahuan umum. Untuk itu pelajaran ilmu pengetahuan agama untuk bisa dimengerti, diamalkan dan dihayati sebagai pembimbing (pemberi roh/jiwa kepada pelajaran ilmu pengetahuan umum. Hal ini diharapkan agar siswa dalam mempergunakan ilmu pengetahuan dengan tujuan memberikan manfaat bagi manusia, dan lingkungan, sehingga bisa menjadi siswa/i yang beriman, bertakwa dan berakhlak mulia.

Selain itu guna lebih menguatkan Pendidikan Agama Islam, MTsN Barabai melaksanakan berbagai kegiatan penguatan, misalnya: 1). Pembuatan Kartu Kendali Ibadah Siswa. Kartu ini diberikan kepada seluruh siswa sejak dia menjadi siswa sampai dia tamat. Dalam kartu kendali ini dimuat berbagai kegiatan siswa melaksanakan ibadah baik pelaksanaan ibadah di lingkungan sekolah maupun di rumah., untuk kegiatan ibadah di rumah siswa haruslah mendapat bimbingan dari orang tua. Setiap kegiatan ibadah siswa harus mendapatkan paraf atau tanda sepengetahuan orang tua. Untuk lebih mengefektifkan keberadaan kartu kendali ibadah siswa maka tiap seminggu sekali tepatnya hari sabtu 
kartu kendali ibadah siswa dikumpulkan ke wali kelas untuk dicek keberadaannya. Dan kartu kendali ibadah siswa ini juga dijadikan monitoring setoran tadarus alqur'an untuk dijadikan prasyarat kenaikan kelas. 2). Khataman Al Qur'an dan Menghapal/Tahfizul Qur'an surah-surah pilihan Khataman Al Qur'an dan Menghapal/Tahfizul Qur'an surah-surah pilihan menjadi kewajiban yang harus dipenuhi seluruh siswa/i, dengan taget minimal: kelas 7 khatam sampai jus 10, kelas 8 khatam sampai jus 15, dan kelas 9 khatam sampai jus 30. Untuk hapalan siswa diwajibkan hapal: klas 7 jus ama, kelas 8 wirid panjang, kelas 9 tahlil dan sholat jenazah. 3). Pengamalan dan Penghayatan setiap hari. Untuk lebih membiasakan siswa beribadah sehari-hari maka MTsN Barabai melaksanakan pembiasaan berupa:

a. Kegiatan rutin diawal pembelajaran pagi hari membaca Al-Quran surah-surah pilihan wirid panjang dengan jadwal sebagai berikut:

Tabel 2:

\begin{tabular}{|c|l|l|}
\hline Hari & \multicolumn{1}{|c|}{ Kegiatan } & Kelas \\
\hline Senin & Membaca Asmaul Husna serta doa belajar & 7,8 , dan 9 \\
\hline Selasa & $\begin{array}{l}\text { Membaca Surah Ar Rahman dilanjutkan } \\
\text { Asmaul Husna serta doa belajar }\end{array}$ & 7,8 , dan 9 \\
\hline Rabu & $\begin{array}{l}\text { Membaca Surah Al Waqiah dilanjutkan } \\
\text { Asmaul Husna serta doa belajar }\end{array}$ & 7,8 , dan 9 \\
\hline Kamis & $\begin{array}{l}\text { Membaca Surah Al Mulk dilanjutkan } \\
\text { Asmaul Husna serta doa belajar }\end{array}$ & 7,8 , dan 9 \\
\hline Jumat & $\begin{array}{l}\text { Membaca Surah Yasin dilanjutkan Asmaul } \\
\text { Husna serta doa belajar }\end{array}$ & $7,8,9$ \\
\hline Sabtu & $\begin{array}{l}\text { Membaca Wirid panjang dilanjutkan } \\
\text { Asmaul Husna serta doa belajar }\end{array}$ & 7 \\
\hline Sabtu & $\begin{array}{l}\text { Membaca Tahlil dilanjutkan Asmaul Husna } \\
\text { serta doa belajar }\end{array}$ & 8 \\
\hline Sabtu & $\begin{array}{l}\text { Membaca Surah As Sajdah dilanjutkan } \\
\text { Asmaul Husna serta doa belajar }\end{array}$ & 9 \\
\hline
\end{tabular}

b. Pada waktu jeda pergantian jam pelajaran siswa diarahkan untuk membaca surahsurah pendek (juz'amma) sampai guru pergantian jam masuk.

c. Pada waktu istirahat pertama jam 09.40 - 10.10 dilaksanakan sholat Dhuha berjamaah di Mushalla. Dikarnakan kapasitas Mushalla terbatas maka sholat
Dhuha dilaksanakan secara bergiliran hari dan kelas. Dengan ketentuan giliran untuk siswa kelas 7 hari senin dan kamis, kelas 8 hari selasa dan jumat, kelas 9 hari rabu dan sabtu.

d. Sholat fardu Zhuhur berjamaah dilaksanakan pada saat istirahat ke dua, tepat dengan masuknya waktu sholat Zhuhur. Untuk pelaksanaan sholat fardu Dzuhur ini dilaksanakan secara berjama'ah oleh seluruh siswa dan guru serta karyawan. Untuk siswi yang berhalangan akan dikumpulkan di ruang perpustakaan dan dibimbing guru tertentu guna membaca sholawat. Hal ini untuk membiasakan siswi menghormati keberadaan orang yang melaksanakan ibadah sholat.

\section{Penguatan Jaringan: Kerjasama Madrasah}

Dalam rangka mengembangkan Madrasah kearah yang lebih maju, maka dilaksanakan kerjasama dengan pihak-pihak tertentu. Di antara kerja sama yang dilaksanakan adalah kerjasama dengan Badan Pengendalian Lingkungan Hidup Kabupaten Hulu Sungai Tengah. Bentuk kerjasama yang dilaksanakan adalah adanya bantuan baksampah permanen dan bak sampah di muka kelas. Selain bak sampah diberikannya bibit tanahan pelindung dan tanaman hias.

Selain dengan BPLH Kabupaten Hulu Sungai Tengah juga dilaksanakan kerjasama dengan lembaga lain baik lembaga pemerintah maupun lembaga swasta.

\section{Inovasi Pendidikan}

Struktur Kurikulum MTsN barabai mengupayakan adanya keseimbangan antara imtaq dan iptek sesuai dengan visi dan misi madrasah. Dengan hal tersebut diharapkan dapat menghasilkan output seorang muslim yang cerdas, religius dan berakhlak mulia.

Program pendidikan di Madrasah Tsanawiyah Negeri Model Barabai meliputi 16 mata 
pelajaran alokasi waktu 50 jam pelajaran setiap minggu. Setiap jam pelajaran berdurasi 40 menit. Jenis program pendidikan di Madrasah Tsanawiyah Negeri Model Barabai, terdiri dari program umum meliputi sejumlah mata pelajaran yang wajib diikuti seluruh peserta didik, dan program pilihan meliputi mata pelajaran yang menjadi ciri khas keunggulan daerah berupa mata pelajaran muatan lokal yang merupakan ciri khas Madrasah Tsanawiyah Negeri Model Barabai. Mata pelajaran yang wajib diikuti pada program umum berjumlah 14, sementara keberadaan mata pelajaran Muatan Lokal ditentukan oleh kebijakan Kemenag Kabupaten Hulu Sungai Tengah dan kebutuhan madrasah.

Pengaturan beban belajar menyesuaikan dengan alokasi waktu yang telah ditentukan dalam struktur kurikulum. Pemamfaatan jam pelajaran tambahan mempertimbangkan kebutuhan peserta didik dalam mencapai kompetensi, di samping memamfaatkan mata pelajaran lain yang dianggap penting namun tidak terdapat di dalam struktur kurikulum yang tercantum di dalam Standar Isi. Dengan adanya tambahan waktu, satuan pendidikan diperkenankan mengadakan penyesuaianpenyesuaian. Misalnya mengadakan program remedial bagi peserta didik yang belum mencapai standar ketuntasan belajar minimal.

\section{Inovasi Kurikulum Agama}

Dalam upaya mensinergikan kemampuan iptek dan imtaq peserta didik. Untuk itulah Madrasah Tsanawiyah Negeri Model Barabai menerapkan inovasi pada kurikulum pendidikan agama Islam dalam bentuk: 1). Muatan lokal berupa program belajar menghafal Juz Amma dan Surah-surah pilihan. 2). Tahsinul Quran yang bertujuan untuk menjadikan peserta didik dapat membaca AlQuran secara fasih. Pelajaran Tahsinul Quran ini dilaksanakan pada jam ke 9 dan ke 10 pada hari senin sampai kamis, berisi pelajaran tajwid secara teori dan praktek secara langsung.

\section{Inovasi Kurikulum Umum}

Guna mencapai tujuan kurikulum dan meningkatkan kualitas hasil belajar peserta didik, Madrasah Tsanawiyah Negeri Model Barabai melakukan terobosan-terobosan sebagai berikut: 1). Pusat Sumber Belajar (PSB) Networking dan virtual class. Pusat Sumber Belajar (PSB) Networkingmerupakan jaringan Intranet (jaringan lokal) yang bisa diakses seluruh warga madrasah melalui wifi yang terhubung pada server PSB sekolah. Dengan fasilitas ini seluruh warga madrasah bisa mengakses konten-konten pembelajaran setiap mata pelajaran serta data-data lainnya seperti, hasil ulangan, data siswa dan tenaga pendidik, dan lain-lain. Disamping itu PSB Networking juga dapat digunakan sebagai sarana konsultasi peserta didik dengan guru, serta sebagai sosial media antar warga madrasah dimana warga madrasah bisa chating, berdiskusi maya dan sebagainya. PSB Networking juga digunakan untuk pembelajaran maya (virtual class). Dengan penggunaan virtual class pembelajaran dan evaluasi dapat berlangsung secara mandiri oleh siswa dengan mengakses konten mata pelajaran meskipun guru yang bersangkutan berhalangan hadir. 2). Pembelajaran Berbasis Alam. Alam semesta yang luas merupakan guru, sumber ilmu pengetahuan tak terbatas. Oleh karena itu Madrasah Tsanawiyah Barabai menerapkan pembelajaran berbasis alam, dimana alam sekitar dijadikan kelas tanpa dinding tanpa batas untuk menggali berbagai macam kompetensi pengetahuan. Guru-guru di Madrasah Tsanawiyah Negeri Model Barabai terbiasa langsung membimbing peserta didik ke alam terbuka untuk mempelajajari materimateri pembelajaran, sehingga diharapkan para siswa tidak hanya faham secara konsep tetapi juga secara konteks. 


\section{PENUTUP}

\section{Kesimpulan}

Dari kajian tentang peningkatan mutu madrasah unggulan pada MTsN Barabai Kalimantan Selatan, ada beberapa hal bisa menjadi kesimpulan, antara lain: 1). MTsN Barabai berhasil menjadi madrasah model dan unggul karena beragam prestasi yang telah diraih. Baikitu prestasi akademis, non akademis, maupun keagamaan. Keberhasilan tersebut diraih karena input siswa sudah pilihan, hasil kerja keras seluruh pengelola madrasah dan siswanya, serta program kebijakan dan pengembangan mutu yang berhasil diimplementasikan dengan baik. 2). Kerja keras dan kreatifitas MTsN Barabai tersebut bisa dijadikan inspirasi bagi madrasah lain di Indonesia, khususnya madrasah tsanawiyah mengingant madrasah ini bisa mengungguli sekolah umum dalam prestasi nilai UN hingga beberapa tahun. Bahan tahun 2014 lima siswanya berhasil masuk Top Five untuk tingkat Provinsi Kalimantan Selatan. 3). Prestasi yang diraih MTsN Barabai menunjukkan bahwa madrasah di daerah yang jauh dari ibukota provinsi bisa mengalahkan sekolah maupun madrasah di kota besar yang akses fasilitas, jaringan dan layanan informasi dan teknologi jauh lebih mudah. Bukti bahwa komitmen, kerja keras, dan kreatifitas membawa madrasah ini menjadi madrasah unggul secara komparatif dan kompetitif dibandingkan dengan madrasah lain maupun sekolah umum.

\section{Rekomendasi}

Kajian ini merekomendasikan: 1) Hendaknya Kementerian Agama senantiasa mendorong pengembangan mutu MTsN Barabai dan memfasilitasi sarana prasarana yang belum dimiliki agar tidak tertiggal dengan sekolah. 2). Hendaknya Kementerian Agama meningkatkan sumber daya pendidik maupun tenaga kependidikan pada jenjang pendidikan yang lebih tinggi dengan memberi ijin belajar maupun beasiswa. 3). Pengembangan mutu pendidikan di MTsN Barabai ini bisa dijadikan model bagi madrasah negeri maupun swasta di Indonesia untuk meningkatkan kualitasnya

\section{SUMBER BACAAN}

Crosby, Phillip B. (1986): Quality Is Free. New York, Mentor Books.

Duke, Daniel L and Robert Lynn Canady (1999.): School Policy. New York: The Drayden Press.

Gamage, David Thenuwara and Nicholas Sun-Keung Pang (2003): Leadership and Management in Education. Hongkong: he Chinese University Press.

Glesne, Corrin dan Peshkin (1992): Becoming Qualitative Researchers: An Introduction. New York: Longman Publishing Group.

Joseph M. Juran (1993): Quality Planning and Analysis/ Third Edition. New York: Mc Graw Hill Inc.

Muhammad, "Konsep Pengembangan Madrasah Unggul", Kreatif, Vol. 4, No. 1 (Januari 2009).

Owens Robert G. (1991): Organizational Behavior in Education. Boston, Allyn and Bacon.

Peter Salim dan Yenny Salim (1991): Kamus Bahasa Indonesia Kontemporer. Jakarta, Modern English Press.

Petrus Trimantara, "Sekolah Unggulan: Antara Kenyataan dan Impian" Jurnal Pendidikan Penabur, Vol. 6, No.08 (Juni 2007), 7.

Peraturan Pemerintah No. 19 tahun 2005, Standar Nasional Pendidikan (Lembaran Negara Repubik Indonesia Tahun 2005 No. 41, Tambahan Lembaran Negara Nomor 4496).

Robert E. Stavin (1991): Educational Psychology: Theory and Practice. New Jersey, Prentice Hall Inc.

Syafaruddin (2008): Efektifitas Kebijakan Pendidikan. Jakarta, Rineka Cipta.

Undang-Undang RI No. 20 Tahun 2003 tentang Sistem Pendidikan Nasional 